\title{
REPORT OF SECTION MEETINGS OF THE NOVEMBER,' 1914, MEETING OF THE CENTRAL ASSOCIATION OF SCIENCE AND MATHEMATICS TEACHERS.
}

\section{Minutes of Agricultural Section.}

Meeting called to order by Prof. A. W. Nolan, Chairman, at 2:45 p. m., November 27, 1914, in Room 215, Hyde Park High School.

After a brief résumé of recent meetings held in the interest of Agricultural Education in the United States the chairman appointed the following nominating committee:

B. M. Davis, Oxford, Ohio.

Car1 Colvin, Carlinville, I11.

F. W. Plapp, Chicago, Inl.

Mr. A. McVittie of Bay City, Mich., and Mr. T. Sexauer of Menomonie, Wis., each assigned a paper on the program of the section, were absent, and their papers were not presented.

Supt. E. J. Tobin, of Cook County Schools, gave an address on "Redirected Rural Education." An interesting general discussion followed this address. Dr. B. M. Davis, of Miami University, Oxford, Ohio, read a paper on "The Amount and Place of Agriculture in a Unified Science Course in the Ordinary Accredited High School."

Mr. Car1 Colvin, of Blackburn College, Carlinville, Ill., read a paper, and illustrated it with lantern slides, on the "Use of Land in Secondary Agriculture."

Mr. E. B. Collett, of DeKalb, Ill., high school read a paper on "The Fighting Chance of Agriculture."

The general discussion which followed the reading of these papers was spirited and full of valuable contributions to the problems of agricultural teaching.

The second session of the Agricultural Section was held Saturday morning, November 28th. Prof. B. M. Davis presided in the absence of the chairman. The nominating committee reported as follows :

President-A. W. Nolan, Urbana, Ill.

Vice President-Mrs. Genevieve Monsch, Gary, Ind.

Secretary-Lester Ivins, Columbus, Ohio.

The report was adopted and the above officers elected for the year 1915 .

Prof. W. H. Smith of the College of Agriculture, University of Illinois, read a paper, "The Teaching of Animal Husbandry in Secondary Schools."

After a general discussion of this and other topics, the meeting adjourned.

HARRY L. BAUER, Sec.

\section{Minutes of Biology Section.}

The Biology section, with about sixty in attendance, was called to order by the Chairman, Mr. Harold B. Shinn, of the Carl Shurz High School of Chicago.

First in order was the appointment by the chair of the nominating committee, consisting of Mr. A. H. Conrad of Crane High School, Chicago; Miss Etta M. Bardwell of Cedar Rapids, Iowa, and Mr. E. S. Tillman of Hammond, Ind.

A very able and interesting paper on "The Present Status of Botanical Teaching in the Normal Schools" was given by Prof. Fred T. Ullrich of the Platteville Normal School, Platteville, Wis.

"The Present Status of Zoölogical Teaching" was discussed by Dr. Elliott R. Downing, of the School of Education, University of Chicago.

1 For the General and Earth Science Section Minutes see the January issue of this Tournal. 
Dr. Downing talked of the position of zoölogy in the high school curriculum and of the methods and aims of zoölogical teaching.

A stimulating paper, "Problems in Teaching Practical Biology," was given by Miss Nettie M. Cook, of Springfield, Ill. She showed how the pupils made practical application of zoology in the home and the community.

As Mr. Frederick C. Lucas, of the Englewood High School, was unable to be present, his paper on "Practical Zoölogy" was read by the secretary. Mr. Lucas showed the necessity of adapting the work to the need of the pupil.

The discussion was opened by Mr. Shinn, who explained how, through the topics of heredity and variation, he leads up to the subject of sex teaching.

Mr. Louis E. Hildebrand, of the New Trier High School of Wilmette, II'., presented a very successful method of handing the difficult subject of sex hygiene in connection with the regular work of zoölogy.

Miss Grace Ellis, of Grand Rapids, Mich., spoke of the aid that should be given the young student in selecting his high school course.

Miss Mabel E. Smal'wood of the Lane Technical High School, Chicago, regretted that pupils in college so often duplicate the work of the high school. She wished that we might do something to prevent this. Moved and carried that the chairman appoint a committee to consider subject of duplication of work of high school and college. Mr. Shinn appointed Miss Smallwood, Mr. Conrad and Mr. Hildebrand on such committee.

Miss Ada L. Weckel of Oak Park, Ill., spoke of the helpful association of parents and teachers and of the exhibits of school work made at such meetings.

Mr. Louis E. Hildebrand of New Trier High School, Wilmette, Ill., described the practical work done in gardening and spraying of trees, all of which arouses great interest in the community.

Mr. J. R. Locke of Detroit, Mich., in reply to a question of the problem of half year science courses, suggested the plan he has tried successfully of a year of botany and a year of zoölogy in alternate years.

Before adjournment Mr. C. L. Holtzman of the Wal'er High School. Chicago, exhibited his display frames made of basswood strips, bought from bee keeper's supplies. These showed how easily and perfectly birds, skeletons, insects, leaves and seeds might be mounted.

$$
\text { Saturiay, November 28Tfi, A. M. }
$$

The report of the committee on duplication of work was given by $\mathrm{Mr}$. Conrad who recommended that this question of duplication be a number on next year's program and that the committee be continued to find out what are the requirements of the colleges.

Moved and carried that the report be accepted and that the committee be continued.

Mr. Conrad, chairman of nominating committee, reports as foilows:

Chairman, Mr. Fred T. Ullrich, Platteville, Wis.

Vice Chairman, Mr. W. A. Pierson, LaFayette, Ind.

Secretary, Miss Nettie M. Cook, Springfield, Ill.

Moved and carried that the secretary cast the white ba'lot for persons nominated.

The rest of the morning was spent in looking at the splendid collection of exhibits brought together. Lantern slides of flowers, birds and insects made and exhibited by Ra!ph E. Wager of DeKalb, Ill., and the slides of flowers and trees, made by Worralo Whitney, of the Hyde Park High School, were much appreciated. 
Mr. A. H. Conrad of the Conrad Slide and Projection Co., showed a valuable collection of slides to illustrate the economic importance of birds.

$\mathrm{Mr}$. Shinn demonstrated the use of some of his microscopic mounts with the lantern.

Mr. Small, of Bausch and Lomb, showed the advantages of the new binocular microscope.

Mrs. Margaret C. Young, of Hyde Park High School, showed her collection of living animals in the laboratory and spoke of her colony of bees on top of the building.

Miss Cook's charts displayed the work of her pupils in their efforts to exterminate the fly.

Moved and carried to accept Mr. Shinn's offer to make a list of places where teachers might obtain various kinds of exhibits. This list he will send to any teacher upon receipt of stamped envelope.

Charlotte H. Stetson, Sec.

\section{Minutes of Chemistry Section.}

The chemistry section of the Science and Mathematics Teachers Association held its first session in Room 312, Hyde Park High School, Chicago, November 27, 1914. Mr. H. M. Ibison, chairman of the section, presided. In the absence of the secretary, H. D. Abells, S. G. Engle, Gary, Indiana, was elected to fill the office pro tem.

Miss Ruth Johnston, Milwaukee-Downer College, Milwaukee, Wis., presented a paper on "High School Preparation for College Work in Science." In the paper, Miss Johnston claimed that the demands which the colleges could put upon the students did not seem worthy of the student nor the subject taught. This she thought was due to lack of preparation for the college work, or that the college requirement was too high. Miss Johnston suggested that the high school sciences be limited to a fewer number, rather than dissipated over the whole field; - that the work be made a problem rather than an entertaining subject; that the teacher be an expert and an enthisiast with a vision, and that the classics be granted a larger place in the high school curriculum.

In the discussion, Mr. Wirick claimed that it was not at all the business of the high school to prepare the student to enter college, and it was a mistake to have in view the preparing for that end. The purpose of the school was to "teach the boys and girls." Mr. Nortis in this connection spoke on school administration and the relation of the high school to the college. He thought there should be a better understanding between the two institutions. Mr. Roecker said that the reason for a lack of understanding was not altogether the fault of the colleges and universitiesthat they were ready and willing to meet the high school half way at any time. Mr. Radcliff said that it was, in his estimation, the duty of the high school to prepare the student for college and more, it was "to teach him to think."

The second paper was by G. C. Ashman, Bradley Polytechnic Institute, Peoria, Ill., on "What Chemistry Should a Girl Have, Who Expects to Become a Teacher of Domestic Science?" Mr. Ashman said it had been his experience that the average domestic science teacher made very little use of her knowledge of chemistry and in reality merely taught "cooking." He thought since so little direct use was made, that we should be careful as to time taken to teach these students also as to the subject. matter taught.

In the discussion of this paper there was a large variety of opinions expressed, both as to whether or not the domestic science teacher uses 